\title{
Organisationsförändring, omsorgsklimat och kvalitet i hemtjänsten
}

BENGT INGVAD, ERIC OLSSON, KARIN BONDESSON \& CHARLOTTE ARNDT

\begin{abstract}
Emotionellt klimat är en betydelsefull kvalitetsaspekt på människobehandlande arbete. I artikeln analyseras hur äldre personers upplevelse av klimatet $i$ mötet med vårdbiträdet förändras när deras hemtjänst organiseras om.
\end{abstract}

\section{Organisationsförändringar under 1990-talet}

Under slutet av 1980-talet och under 1990talet skapades förväntningar på att en förändrad organisation skulle höja kvaliteten på äldreomsorgen och göra den mera kostnadseffektiv (Olsson \& Ingvad 2006a). Kritiken mot offentlig sektor, en vikande ekonomi och en politisk omorientering mot nyliberalism drev fram en förändringsprocess inom den offentliga sektorn. Inom hemtjänsten, som har en nyckelroll i offentlig vård av äldre, infördes privatise-

Bengt Ingvad är fil dr i socialt arbete.

Eric Olsson är professor i socialt arbete.

Karin Bondesson är fil.kand.

Charlotte Arndt är fil.mag. i socialt arbete.

Samtliga vid Socialhögskolan i Lund. ringar och nya styr- och ledningsformer och försök gjordes att platta ut organisationen. Idag har hälften av landets kommuner avtal med privata aktörer inom äldreomsorgen och en delad organisation (beställar-utförarmodell) har införts i 80 procent av landets kommuner (Socialstyrelsen 2004).

Hemtjänstens verksamhet har berörts av reformeringen av handikappomsorgen och psykiatrin, neddragningar inom sjukvården och ökningen av antalet äldre personer i befolkningen. Insatserna har kommit att koncentreras på en mindre och alltmer hjälpbehövande grupp av äldre (Szebehely 2000).

\section{Begreppet omsorgsklimat}

Tre huvudsakliga processer är involverade 
i formell omsorgsverksamhet. Var och en måste betraktas i ljuset av de andra. En process är samspelet inom organisationen för äldreomsorg i kommunen. Denna inkluderar ansvarsfördelning, kommunikation, ledning såväl som organiseringen av arbetet i de äldres hem (Ingvad 2003, Olsson et al. 1995, Szebehely 1995). En andra process inkluderar föreställningar, förväntningar och tolkningar av situationen från olika parter på olika nivåer i organisationen, t.ex. hur arbetet ska bedrivas och vilka de andra parterna är. Den tredje processen handlar om samspelet mellan den gamla och vårdbiträdet under omsorgsarbetet i vårdtagarens hem. Ömsesidig påverkan av tankar och känslor i denna interaktion bildar ett känslomässigt samspel ur vilket en relation mellan parterna och en stämning, ett klimat växer fram (Ingvad 2003). Vårdtagaren och vårdbiträdet konstruerar tillsammans relationen utifrån innehållet i detta känslomässiga samspel (se Figur 1). Det vi kallar omsorgsklimat är ett uttryck för karaktären i det känslomässiga samspelet mellan den äldre och vårdbiträdet.

Klimatbegreppet används för att benämna karaktären i de emotionella processer som uppstår ur mellanmänskligt samspel (se t.ex. Aspelin 1999, Lewin et al. 1939, Olsson 1998). Begreppet vårdatmosfär (ward atmosphere) beskriver klimatet i team som utför vård eller terapi (Gilbert \& Levinson 1956, Mackenzie 1981, Rapoport 1960). Vårdatmosfär med klarhet, stöd och engagemang har visat sig ha positiv effekt för patienternas tillfrisknande (O'Driscoll \& Evans 1988). Timko och Moos (1991) har i en nationell studie i USA visat att klimatet i vårdboenden för äldre av typen stödjande och autonomt, dold konflikt och avvisande varierar med ägandeformen. I undersökningar av vilket klimat i den psykoterapeutiska relationen som ger bra resultat lägger Rogers et al. (1967) vikt vid en tillåtande hållning, stöd och empatisk attityd från terapeuten. Dessa olika studier visar att emotionellt klimat är en betydelsefull kvalitativ aspekt på relationer i människobehandlande arbete.

\section{Omsorgsklimatet $i$ hemtjänsten}

Vi har visat att mötet mellan vårdtagaren och vårdbiträdet innehåller en hög grad av känslomässigt beroende (Ingvad 2003, Ingvad \& Olsson 1999). Till båda parters förväntningar på relationen hör bl.a. sociala behov som erkännande, respekt och uppskattning. I samspelet sammanvävs dessa behov med omsorgshandlingarna, vilket innebär att en strävan att infria de sociala målen blir del av parternas handlingar kring omsorgen. Huruvida de sociala målen förverkligas eller inte bidrar till vilken innebörd omsorgsrelationen får för parterna, vilket påverkar omsorgshandlingarna och gensvaret på dessa (Ingvad 2003). Exempelvis uppfattas vänskapliga omsorgsrelationer av de äldre ofta som respektfulla och jämbördiga, och närhet uppfattas av vårdbiträden som ett tecken på deras kompetens.

Tidigare har vi undersökt vilka faktorer som påverkar den gamlas och vårdbiträdets upplevelser av omsorgsklimatet (Ingvad 2003, Olsson \& Ingvad 2001). Ett splittrat gruppklimat i vårdbiträdesgruppen har t.ex. ett tydligt samband med att vårdtaga- 
Figur I.

En modell för konstruktionen av omsorgsklimatet inom hemtjänst.

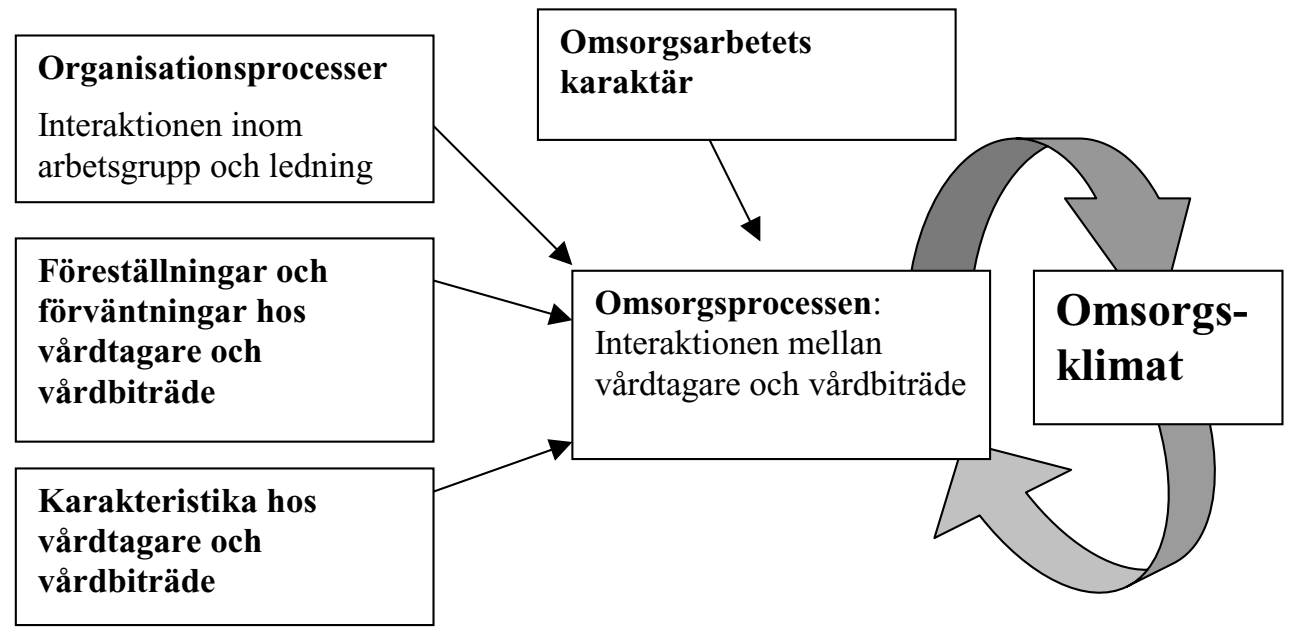

ren upplever osäkerhet i relationen till vårdbiträdet. Ett vänskapligt eller konfliktartat omsorgsklimat är oftast ömsesidigt, medan om den ena parten upplever klimatet som mer formellt och rationellt kan den andra parten uppleva närhet.

\section{Problemformulering och syfte}

Kommunernas äldreomsorgsorganisationer har under 1990-talet brutits upp och förändrats i olika takt och på olika sätt, vilket rimligen påverkat arbetet $\mathrm{i}$ hemtjänsten och vårdtagarnas upplevelser av hjälpen. Centralt i allt omsorgsarbete är relationen mellan omsorgsgivaren och omsorgsmottagaren. I detta arbete studerar vi den äldres upplevelse av omsorgsklimatet som ett mått på kvaliteten i hemtjänsten. Syftet är att undersöka om och hur olika organisationsformer och förändringar av dessa återver- kar på den äldres upplevelse av omsorgsklimatet och därmed på omsorgskvaliteten. Vårdtagare har tillfrågats vid tre tillfällen under en tioårsperiod samtidigt som vi följt organisationens förändringar. Vi gör två typer av analyser. En longitudinell analys utförs av sju distrikt där vi utifrån kvalitativa beskrivningar av organisationerna undersöker hur omsorgsklimatet förändras i förhållande till genomförda förändringar. I den andra analysen betraktar vi varje distrikt vid varje undersökningspunkt som en speciell typ av organisation och utför korrelationsstudier och regressionsanalyser för förhållandet mellan organisationskarakteristika och omsorgsklimat.

\section{Olika organisationsmodeller}

Förändringen av organisationen för äldreomsorgen startades i stort sett i landets 
Tabell I.

Förändringar inom äldreomsorgen under 1990-talet.

\begin{tabular}{|l|l|}
\hline Motiv & Förändring \\
\hline Samordning av resurser & $\begin{array}{l}\text { ÄDELreformen - samordning av social service och } \\
\text { sjukvård. }\end{array}$ \\
\hline Medborgarrättigheter och medborgarinflytande & $\begin{array}{l}\text { Delning av organisationen i beställare och utförare } \\
\text { - specialiserade handläggare gör bedömningar av } \\
\text { rätt till bistånd. }\end{array}$ \\
\hline Effektivisering av styrning och ledning & $\begin{array}{l}\text { Beställar-utförarmodellen samt konkurrensutsätt- } \\
\text { ning. }\end{array}$ \\
\hline
\end{tabular}

samtliga kommuner. De olika motiven och förändringsmodellerna sammanfattas i Tabell 1.

Samordning i organisationen har skapats genom reformer. Genom Ädelreformen har kommunerna tagit över ett större ansvar för de äldres sjukvård. En annan förändring har varit att politikerna inte ska bära direkt ansvar för verksamheterna utan enbart beställa och upphandla service och vård. Detta kallas allmänt för beställar-utförarmodellen (Andersen 2000, Blomberg 2004, Fuglsang 2001, Kitchener 1998, Trydegård 2001, Ware et al. 2001). En avdelning i organisationen bedömer vårdbehov och beställer vård av en utförande verksamhet. Den senare ansvarar för organisationen av arbetet och upprätthållandet av arbetsmiljön. Modellen möjliggör konkurrensutsättning där utförandet av hemtjänsten beställs från privata eller kommunala företag. Ett argument för att införa beställar-utförarmodellen har varit att den anses bättre tillgodose den enskilde medborgarens rättigheter och möjligheter att göra egna val. Tidigare utförde arbetsledare behovsbedömningar och bestämde hjälpinsatsens omfattning för de äldre.

Tung hierarki och brist på möjligheter till självständiga initiativ från personalen skulle avhjälpas genom ett minskat antal nivåer och mer självständighet åt varje arbetsenhet. Denna process kallas utplattning, och följden har oftast blivit färre arbetsledare med ansvar för fler anställda. I några fall har självstyrande eller autonoma grupper införts.

Ett betydelsefullt motiv har varit de ökade kostnaderna. Konkurrensutsättning och resultatenheter har ansetts tvinga fram lägre priser och förmå de anställda att bli mer kostnadsmedvetna och aktiva i besparingssträvanden. Det har dock också handlat om en ideologisk och samhällsekonomisk fråga om hur höga skatter man kan ta ut av befolkningen.

\section{Metoder}

Materialinsamlingen - postenkäter till vårdtagare och vårdbiträden; observatio- 
ner och intevjuer med ledning och vårdpersonal - ha genomförts vid fyra tillfällen: 1993, 1995, 1997 och 2002/2003 (december 2002-april 2003). Mätningen av vårdtagarnas upplevelse av omsorgsklimatet med enkäter genomfördes 1995, 1997 samt 2002/2003.

\section{Organisationsformer}

Organisationsformen har bedömts utifrån intervjuer med ledningspersonal och observationer vid möten i vårdbiträdesgrupperna.

Organisationerna karaktäriseras genom följande variabler:

1. Kommun- och distriktsstorlek beskrivs i tusental invånare.

2. Grad av delad organisation beskrivs i tre nivåer: Traditionell organisation utan beställar-utförarorganisation (1); Beställar-utförarorganisation utan konkurrensutsättning (2); Beställar-utförarorganisation med konkurrensutsättning (3).

3. Grad av utplattning beskrivs i tre nivåer: Arbetsledare i varje arbetsgrupp med i stort sett ständig tillgänglighet (1); Arbetsledare med ansvar för flera grupper med relativt god tillgänglighet (2); Arbetsledare med ansvar för flera grupper med begränsad tillgänglighet (3). God tillgänglighet innebär att arbetsledaren kan nås vid alla tidpunkter, medan begränsad tillgänglighet innebär att arbetsledaren bara kan nås vid vissa tidpunkter under veckan, oftast i samband med möten.
4. Grad av arbetsbörda beräknas som procent vårdtagare med daglig vård $(\mathrm{jmf}$ Olsson \& Ingvad 2000).

Förutom organisationens formella karaktär har samspelsförhållanden och förändringsprocesser i distrikten kartlagts i en kvalitativ beskrivning utifrån observationer av arbetsgruppernas verksamhet och intervjuer med ledning och personal (Olsson \& Ingvad 2000, 2004).

\section{Mätning av omsorgsklimat}

En lista med 85 adjektiv, som representerar vanligt förekommande beskrivningar av atmosfären i relationer, presenteras för vårdtagarna i en postenkät. Vårdtagarna ska ange minst 15 ord som de anser karaktäriserar stämningen i relationen till vårdbiträdena. Vårdtagarna ombeds ge en sammantagen bild av relationen till samtliga vårdbiträden som besöker dem. Genom faktoranalys (Olsson \& Ingvad 2000) har vi extraherat fyra omsorgsklimatfaktorer för vårdtagarnas upplevelse av relationen till vårdbiträdet (se Tabell 2). För varje faktor beräknas ett index enligt formeln: (Antal svar på faktorn/antal ord som ingår i faktorn)/(antal svar på formuläret/85). Nämnaren i formeln utgör en korrektion för hur många ord man väljer på formuläret. Även om instruktionen är att välja 15 ord finns en variation i antalet valda ord.

Faktorn osäkerhet innehåller ord som anknyter till oro och ängslan, uttryck för irritation men även ord som antyder brist på ordning. Sammantaget anger faktorn att relationen präglas av osäkerhet och nega- 
tiva känslor. Denna faktor anknyter till en dimension som gäller säkerhet och trygghet i relationen.

Faktorn närhet innehåller ord som har med värme och positiva känslor att göra. Denna faktor anknyter till graden av intimitet och närhet i relationen.

Faktorn kommunikation innehåller ord som anger att relationen präglas av en öppen kommunikation som upplevs som spontan och naturlig.

Faktorn kontroll/ordning innehåller ord som anger att relationen präglas av säkerhet och mognad samt att den är viktig. Faktorn kan antas anknyta till att vårdtagaren upplever kontroll över relationen och därmed har den med maktdimensionen i relationen att göra.

Kombinationen av de fyra klimatindexen kan betraktas som en beskrivning av vårdtagarens upplevelse av klimatet i relationen till vårdbiträdet. Genom en klusteranalys (Olsson \& Ingvad 2000) har ett antal olika profiltyper kunnat beskrivas. En profil kallas rationellt klimat och präglas av höga värden på Kontroll/Ordning, medelhög Osäkerhet och Närhet samt låg Kommunikation. En profiltyp kallas vänskapligt klimat som har hög Kommunikation, låga värden på Osäkerhet och Kontroll/Ordning samt medelhög Närhet. Profilen emotionellt klimat präglas av mycket hög Närhet, relativt låga värden på Kontroll/Ordning och Kommunikation samt medelhög Osäkerhet. En profil kallas osäkert klimat och präglas av mycket hög Osäkerhet och låga värden på övriga index.

Vi har prövat omsorgsklimatinstrumentets validitet genom att undersöka dess samband med kända mått på omsorgskvali- tet. De beräknade indexen visar höga korrelationer med vårdtagares upplevelser av information och delaktighet $i$ vårdens uppläggning och ett mått på tillfredsställelsen med omsorgen överlag (Olsson \& Ingvad 2000). Värdena för osäkerhet visar starka negativa samband med bedömningen av hjälpen. I en annan studie (Olsson \& Ingvad 2001) erhölls höga korrelationer mellan de ingående indexen och ett mått på personkontinuitet, som är ett välkänt kvalitetsmått. Liknande resultat har vi även funnit i en senare studie (Olsson \& Ingvad 2006b). Utifrån dessa validitetsprövningar kan man betrakta mätningen av omsorgsklimatet som ett mått på omsorgskvalitet i hemtjänsten. Instrumentet har en tillfredsställande reliabilitet (Olsson \& Ingvad 2000).

\section{Material}

Studien omfattar sju distrikt i tre kommuner (se Olsson \& Ingvad 2000). Kommunerna är valda för att representera de vanligaste kommuntyperna i Sverige. Kommun A utgör en relativt liten kommun (ca 9000 inv) med några tätorter med industri och omgivande glesbebyggda skogsområden. Kommun B (ca 25000 inv) utgörs av en liten stad (16 000 inv), som är omgiven av slättbyggd. Kommun C är en stor stad (ca 271000 inv). Organisationsförändringarna har utförts i olika utsträckning och vid olika tidpunkter i de tre kommunerna (se Tabell 3).

Antalet vårdtagare minskar successivt vid de två senare mättillfällena. Troligen beror detta dels på att antalet hjälpbehövande äldre i en del av distrikten sjunker, dels på att kraven på hjälpbehov för att få 
Tabell 2.

Adjektiv som ingår i faktorer för vårdtagares upplevelse av relationen till vårdbiträdet i hemtjänsten.

\begin{tabular}{|l|l|l|l|}
\hline Osäkerhet & Närhet & Kommunikation & Kontroll/Ordning \\
\hline Oroligt & Kärleksfullt & Öppet & Vuxet \\
Rörigt & Varmt & Hänsynsfullt & Självständigt \\
Irriterat & Harmoniskt & Lättsamt & Säkert \\
Osäkert & Lyckligt & Aktivt & Moget \\
Nervöst & Ödmjukt & Lugnt & Ordnat \\
Likgiltigt & Berömmande & Personligt & Viktigt \\
Jäktat & Behagligt & Lätt & Förnuftigt \\
Splittrat & Tryggt & Tolerant & Meningsfullt \\
Opersonligt & & Solidariskt & Stabilt \\
& & Naturligt & \\
& & Spontant & \\
\hline
\end{tabular}

\section{Tabell 3.}

Beskrivning av organisationsförändringarna i de olika distrikten under perioden 19932003.

\begin{tabular}{|c|c|}
\hline Distrikt & Organisationsformer \\
\hline $\begin{array}{l}\text { Ekvallen ( } 1200 \text { inv); } \\
\text { Kommun A }\end{array}$ & $\begin{array}{l}\text { Små autonoma arbetsgrupper, ıtraditionell organisation« } 1993- \\
200 \text { I. År } 200 \text { I delning i beställar-utförarorganisation utan konkur- } \\
\text { rensutsättning. }\end{array}$ \\
\hline $\begin{array}{l}\text { Moheden (3000 inv); } \\
\text { Kommun A }\end{array}$ & $\begin{array}{l}\text { Små arbetsgrupper, »traditionell organisation« 1993-200 I. } 1996 \\
\text { omorganisering av arbetsgrupperna och förändring av deras } \\
\text { ansvarsområden. År } 200 \text { I delning i beställar-utförarorganisation } \\
\text { utan konkurrensutsättning. }\end{array}$ \\
\hline $\begin{array}{l}\text { Centrum (3000 inv); } \\
\text { Kommun B }\end{array}$ & $\begin{array}{l}\text { Utplattning av organisationen 1992. } 1996 \text { delning i beställar-utfö- } \\
\text { rarorganisation utan konkurrensutsättning. Förstärkt arbetsle- } \\
\text { darskap 1998. Arbetsgruppen delas i två grupper 200I. }\end{array}$ \\
\hline $\begin{array}{l}\text { Slätten ( } 1400 \text { inv); } \\
\text { Kommun B }\end{array}$ & $\begin{array}{l}\text { Utplattning av organisationen 1992. År } 1996 \text { delning i beställar- } \\
\text { utförarorganisation utan konkurrensutsättning och förstärkt } \\
\text { gruppledarskap. } 1997 \text { sammanslagning av distriktets två arbets- } \\
\text { grupper. Förstärkt arbetsledarskap 1998. }\end{array}$ \\
\hline $\begin{array}{l}\text { Privaten I (3000 inv); } \\
\text { Kommun B }\end{array}$ & $\begin{array}{l}\text { I } 992 \text { konkurrensutsättning i samband med Ädelreformen. Drivet } \\
\text { av ett privat företag under hela studietiden. (Kommunal drift från } \\
\text { januari 2004.) }\end{array}$ \\
\hline $\begin{array}{l}\text { Kommunal (5000 inv); } \\
\text { Kommun C }\end{array}$ & $\begin{array}{l}\text { Från } 1993 \text { beställar-utförarorganisation med kommunal drift. } \\
\text { Åtskilliga förändringar av administration och sammansättning av } \\
\text { arbetsgrupper under hela studieperioden. } 2001 \text { mindre arbets- } \\
\text { grupper och förstärkt arbetsledning. }\end{array}$ \\
\hline $\begin{array}{l}\text { Privaten } 2 \text { (6000 inv) } \\
\text { Kommun C }\end{array}$ & $\begin{array}{l}\text { Beställar-utförarmodell från } 1993 \text { med konkurrensutsättning. } \\
\text { Drivet av två privata företag från } 1993 \text { respektive 1997. Kom- } \\
\text { munal drift från 2001. }\end{array}$ \\
\hline
\end{tabular}

Ingvad, Olsson, Bondesson \& Arndt: Organisationsförändring, omsorgsklimat... 
hemtjänst har höjts. Personkontinuiteten (här antalet vårdbiträden vårdtagarna upplever att de får hjälp av) försämras i distrikten från 1995, och 2002/2003 överväger gruppen äldre med fler än tre vårdbiträden. Andelen vårdtagare med daglig vård ökar stegvis under åren 1995 till 2002/2003 liksom deras medelålder, från en spridning mellan distrikten 1995 på 76-83 år till en spridning på 76-87 år 2002/2003. Överlag är kvinnorna i majoritet bland vårdtagarna vid de olika mättillfällena, en tämligen konstant andel på 56-88 procent i respektive distrikt. Förändringarna av omsorgens karaktär och tyngd i distrikten under studietiden överensstämmer med tendenserna inom hemtjänsten i hela landet under 1990talet (jmf Szebehely 2000).

\section{Bortfall}

Bortfallet i undersökningen av vårdtagarnas upplevelser av omsorgsklimatet har i samtliga distrikt vid de olika mättillfällena varit cirka 30 procent eller strax däröver. Vid mätningen 2002/2003 är bortfallet i distrikten 25-40 procent. Distrikt Kommunal har vid denna mätning ett allt för stort bortfall (50 \%) för att resultatet ska anses tillförlitligt. Skälet kan vara att kommunen nära i tiden har skickat ut enkäter av liknande karaktär för kvalitetssäkring. Kanske kan vårdtagarna därför ha ansett att de redan besvarat enkäten.

\section{Resultat}

I detta avsnitt undersöker vi förhållandet mellan förändringar i organisationen och de äldres upplevelser av omsorgsrelationen genom en analys av varje distrikt för sig. Endast i några fall är resultaten kring omsorgsklimatet statistiskt signifikanta. Trots det anser vi att resultaten är intressanta.

\section{Ekvallen, kommun $A$}

Utmärkande för Ekvallen är att organisationen varit tämligen oförändrad fram till 2001 (se Figur 2). Distriktet har tre små självständiga arbetsgrupper för dagtid sedan slutet av 1980-talet, då vårdbiträdena utbildades i lagarbete. Utplattning har skett $i$ ringa omfattning och tillgängligheten till arbetsledaren har varit god under hela perioden (se också Olsson et al. 1995). Ädelreformen, genomförd i kommunen 1992, har medfört viss osäkerhet i distriktets arbetsgrupper, bl.a. kring medicinutdelningen. Införandet av specialiserad biståndsbedömning i kommunen 2001 har inneburit att dessa arbetsuppgifter har tagits från distriktet och lagts på två handläggare, gemensamma för hela kommunen. Genomförandet har skett under starka motsättningar mellan politiker/äldreomsorgsledning och arbetsledare. Politikerna har hanterat denna konflikt genom att kräva lydnad av arbetsledarna. Någon dialog mellan parterna i konflikten förefaller inte ha ägt rum. 2002/2003 fanns en kvarstående konflikt på ledningsnivå. Arbetsledaren i Ekvallen har varit negativ till förändringen och anser att den har inneburit en sämre omsorg om de äldre.

I Ekvallen finns 1995 en stor andel vän- 


\section{Figur 2.}

Organisationsförändringar och fördelningen av de äldres upplevelser av omsorgsklimatet ( $i$ procent) vid de tre mättillfällena i distriktet Ekvallen.

\section{Ädelreformen}

Delning i beställare/utförare utan konkurrensutsättning

\begin{tabular}{|c|c|c|c|}
\hline Ekvallen & 1995 & 1997 & 2002/2003 \\
\hline Omsorgsklimat & procent & procent & procent \\
\hline Vänskapligt & 48 & 42 & 30 \\
\hline Osäkert & 13 & 8 & 0 \\
\hline Emotionellt & 17 & 42 & 50 \\
\hline Rationellt & 22 & 8 & 20 \\
\hline
\end{tabular}

skapligt omsorgsklimat, som sedan minskar. 1995 finns en låg andel osäkert klimat, som är helt försvunnen 2002/2003. Vi kan tänka oss att vi 1995 har kvarstående effekter av Ädelreformen som skapat osäkerhet bland vårdbiträdena och konflikter med distriktssköterskor, vilket kan ha haft betydelse för några vårdtagares upplevelser. Andelen emotionellt klimat ökar betydligt under perioden, vilket till en del kan förstås i förhållande till en ökad proportion vårdtagare med daglig vård 2002/2003. Sannolikt bidrar detta till ett starkare beroende från vårdtagarens sida och en starkare känslomässig bindning mellan vårdbiträde och vårdtagare.

I positiv riktning verkar förmodligen att distriktet har en stark kontinuitet med samma arbetsledare. Personalomsättningen i arbetsgrupperna har också varit låg (Olsson et al. 2005). Överlag tyder den låga andelen osäkra klimat och en relativt hög andel vänskapliga klimat i förhållande till andra distrikt på att omsorgsarbetet i distriktet har hög kvalitet under hela perioden.

\section{Moheden, kommun A}

Omorganiseringen i distriktet 1996 i samband med öppnandet av ett serviceboende innebar att helt nya hemtjänstgrupper skapades och att gruppernas ansvarsområden förändrades (se Figur 3). I jämförelse med Ekvallen har grupperna varit något större i Moheden men har haft god tillgänglighet till arbetsledare under hela tidsperioden. Arbetsgrupperna har varit mindre självständiga och har inte haft samma möteskontinuitet som Ekvallens grupper (se vidare Olsson et al. 1995).

I detta distrikt av kommun A ser vi inte några kvarstående effekter av Ädelreformen i andelen osäkra klimat 1995. Först två år senare har andelen osäkert klimat höjts kraftigt. Troligen är detta en effekt av omorganiseringen 1996 av arbetsgrup- 
Figur 3.

Organisationsförändringar och fördelningen av de äldres upplevelser av omsorgsklimatet $(i$ procent) vid de tre mättillfällena i distriktet Moheden.

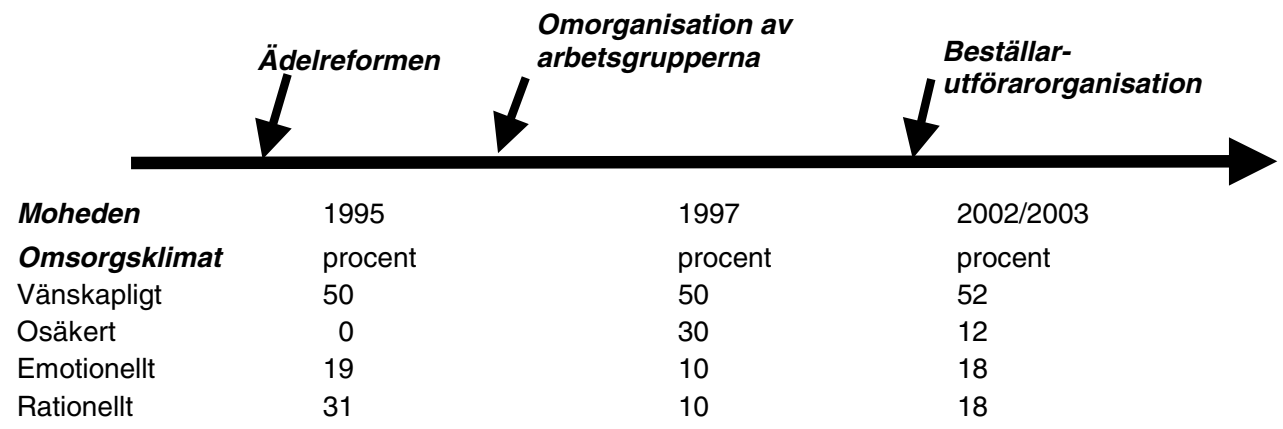

perna. Flera vårdtagare har fått byta vårdbiträde, och gruppklimatet försämrades i arbetsgrupperna (se Olsson et al. 2005).

Omsorgsrelationen kan ses som något förbättrad 2002/2003, då andelen osäkert klimat har sjunkit. Det kontinuitetsbrott i gruppsammansättningen och omsorgsrelationer som ägde rum 1996 har troligen reparerats vid denna tidpunkt. Eventuellt kan införandet av en beställar-utförarorganisation ha haft en positiv effekt.

\section{Centrum, kommun B}

Distrikten i kommun B plattades ut samtidigt som Ädelreformen genomfördes 19921993 (se Figur 4). Den studerade arbetsgruppen i Centrum fick dela områdeschef med flera andra grupper. Tillgänglighet till områdeschefen var begränsad, som överlämnade en del av arbetsledningen till en samordnare utan formell status. 1999 förstärktes ledarskapet genom en utökning av antalet enhetschefer.
Distriktets vårdtagare upplever i stor utsträckning osäkra omsorgsklimat 1995. I jämförelse med andra distrikt vid olika tillfällen är det en mycket hög andel osäkert klimat. Detta hör med stor sannolikhet samman med en betydligt försämrad tillgänglighet till arbetsledaren för personalen. Även genomförandet av ÄDEL, som ledde till konflikter kring medicinutdelning under 1993-1995, kan ha haft betydelse. Andelen osäkert klimat är halverad vid de följande två mättillfällena. Det skulle snarast kunna bero på att personalen lärt sig det nya arbetssätt som Ädelreformen medfört. Möjligen kan även införandet av särskilda biståndsbedömare bidra till en nedgång av andelen osäkert klimat 1997. Vid detta mättillfälle har andelen rationellt klimat ökat, en ökning som är jämförbar med den i distrikten Ekvallen och Moheden vid samma organisationsförändring.

Det förefaller inte som ett förstärkt ledarskap och en delning av arbetsgruppen har skapat bättre förutsättningar för de äldres upplevelser av omsorgsklimatet 


\section{Figur 4.}

Organisationsförändringar och fördelningen av de äldres upplevelser av omsorgsklimatet ( $i$ procent) vid de tre mättillfällena i distriktet Centrum.

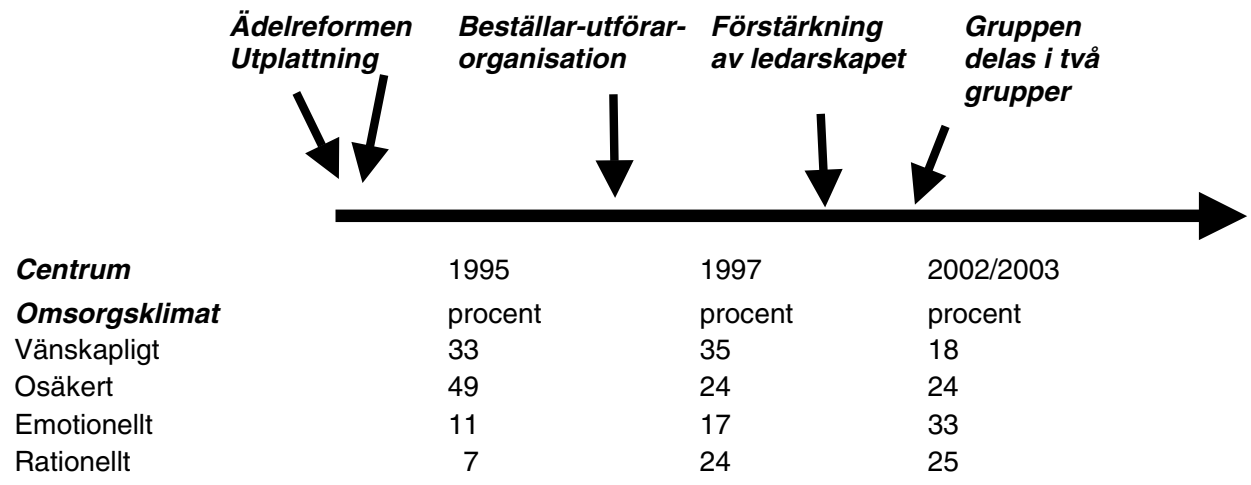

2002/2003. Andelen osäkra klimat är kvar på samma nivå. Förändringarna kan eventuellt ha motverkat varandra. Omorganiseringen av gruppen kan ha betytt att ett antal vårdtagare har fått byta vårdbiträde. Vid mättillfället har andelen vänskapligt klimat minskat samtidigt som andelen emotionellt klimat ökat. Bidragande till denna fördelning är förmodligen att andelen vårdtagare med daglig vård ökar.

\section{Slätten, kommun B}

Slätten genomgår samma större organisationsförändringar som övriga distrikt $i$ kommunen (se Figur 5). Utmärkande är att detta landsbygdsdistrikt 1993 i praktiken har två små arbetsgrupper (lokaliserade $\mathrm{i}$ två mindre orter) som den administrativa ledningen betraktar som en grupp. Först 1997 slås de samman och utgår från samma lokal, som ett led i effektivisering.

Andelen vänskapligt klimat är ovanligt högt 1995. En trolig tolkning är att arbetsgruppernas historia och den bekantskap med befolkningen som följer med arbete i ett landsbygdsdistrikt fortfarande präglar verksamheten vid denna tidpunkt. Andelen osäkert klimat ökar kraftigt 1997 och andelen vänskapligt klimat minskar. Detta kan förstås mot bakgrund av den osäkerhet som skapas bland vårdtagarna när en av arbetsgrupperna flyttas och när vårdtagare tvingas byta vårdbiträden. Införandet av centralt placerade biståndshandläggare året före kan vara en förändring i distriktet som medverkar till ökningen i osäkra klimat. Osäkert klimat sjunker till en tämligen låg nivå 2002/2003. Utökningen av antalet arbetsledare i distriktet kan ha bidragit till detta.

Framförallt rationellt klimat ökar kraftigt i andel 2002/2003 utifrån en tidigare ovanligt låg nivå. Även emotionellt klimat ökar en del vid detta mättillfälle. Fördelningen av de olika typerna omsorgsklimat 2002/2003 jämfört med 1995 talar för att

Ingvad, Olsson, Bondesson \& Arndt: Organisationsförändring, omsorgsklimat... 
Figur 5.

Organisationsförändringar och fördelningen av de äldres upplevelser av omsorgsklimatet $(i$ procent) vid de tre mättillfällena i distriktet Slätten.

$\begin{array}{llll}\begin{array}{l}\text { Ädelreformen } \\ \text { Utplattning }\end{array} & \begin{array}{l}\text { Beställar- } \\ \text { utförarorgani- } \\ \text { sation }\end{array} & \begin{array}{l}\text { Gruppsamman- Förstärkning av } \\ \text { slagning } \\ \text { ledarskapet }\end{array} \\ \text { Slätten } & 1995 & 1997 & 2002 / 2003 \\ \text { Omsorgsklimat } & \text { procent } & \text { procent } & \text { procent } \\ \text { Vänskapligt } & 60 & 35 & 32 \\ \text { Osäkert } & 16 & 38 & 9 \\ \text { Emotionellt } & 20 & 19 & 32 \\ \text { Rationellt } & 4 & 8 & \end{array}$

omsorgsarbetet har en förändrad karaktär, med möjligen en minskad kontinuitet mellan vårdbiträden och vårdtagare. Distriktet har en stor ökning av proportionen vårdtagare med daglig vård från 1997 till 2002/2003.

\section{Privaten 1, kommun B}

Privaten 1 är det enda distrikt i studien som har varit privatiserat under hela studieperioden (se Figur 6). Samma privata företag har innehaft entreprenaden under hela perioden och inga andra förändringar har tillkommit. Arbetsgruppen har inte omorganiserats och ledarskapet har inte förändrats.

Vid de två första mättillfällena är andelen osäkert och vänskapligt omsorgsklimat stabila, men andelen osäkert klimat stiger till en mycket hög andel 2002/2003. Samtidigt sjunker andelen vänskapligt och rationellt klimat. Här är organisationsformen konstant, vilket innebär att förändringarna måste tillmätas försämringar i den privata organisationen som en följd av bla. effektiviseringssträvanden. Försämring av gruppklimatet i den studerade arbetsgruppen tyder på detta (se Olsson et al. 2005). Distriktet har små förändringar i proportionen vårdtagare med daglig vård varför arbetsbördan knappast kan bidra till de negativa förändringarna i omsorgsklimaten. Dock sker det en förändring av kontinuiteten. 1995 uppger elva procent av vårdtagarna att de har tre eller fler vårdbiträden, medan andelen 2002/2003 är 41 procent.

\section{Kommunal, kommun C}

Kännetecknande för detta distrikt är att en beställar-utförarorganisation införs redan 1993 och att det sker omorganiseringar av arbetsgrupper och förändringar av upptagningsområde (se Figur 7). En utplattning äger rum 1993, så att ledarskapet sköts genom en områdeschef som delegerar ledarskapet till samordnare eller gruppernas 


\section{Figur 6.}

Organisationsförändringar och fördelningen av de äldres upplevelser av omsorgsklimatet ( $i$ procent) vid de tre mättillfällena i distriktet Privaten 1.

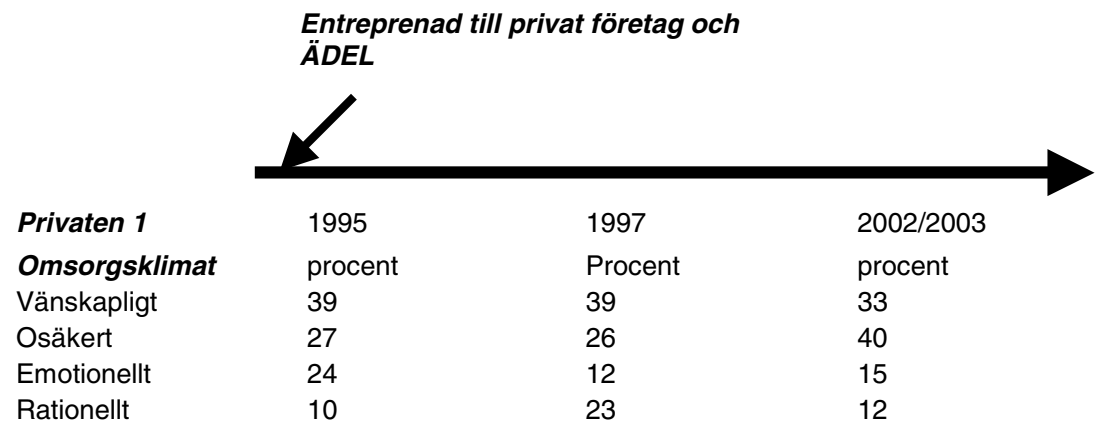

\section{Figur 7.}

Organisationsförändringar och fördelningen av de äldres upplevelser av omsorgsklimatet ( $i$ procent) vid de tre mättillfällena i distriktet Kommunal.

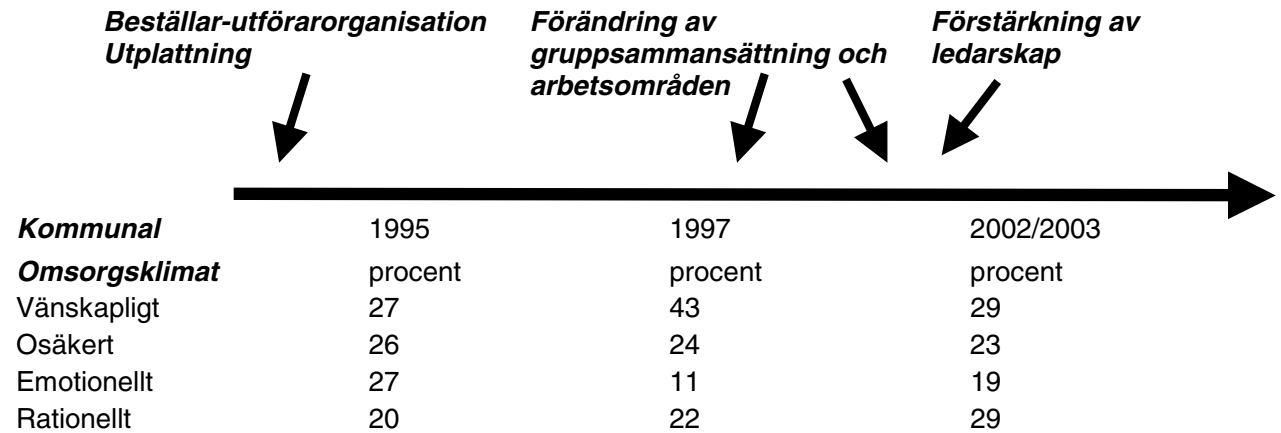

självstyre. Gruppen slås samman med en annan grupp 1997, för att åter delas 2001. En ökning av antalet arbetsledare sker 2001. Ädelreformen sätts på allvar i verket i slutet av 1990-talet med sammanslagning av hemtjänst och hemsjukvård och utbildning av en del vårdbiträden till undersköterskor.

Andelen osäkert klimat är tämligen konstant, och de enda större förändringarna under perioden sker för vänskapligt och emotionellt klimat. Däremot är andelen osäkert klimat hög i förhållande till andra distrikt. Detta kan tolkas som en beständig otillfredsställdhet med omsorgen hos vårdtagare, vilket kan relateras till en kraftig förändring tidigt under perioden, då organisationen både delas i beställare-utförare och utplattas. 
Figur 8.

Organisationsförändringar och fördelningen av de äldres upplevelser av omsorgsklimatet $(i$ procent) vid de tre mättillfällena i distriktet Privaten 2.

$\begin{array}{llll}\begin{array}{l}\text { Entreprenad till privat } \\ \text { företag }\end{array} & \text { Nytt företag } & \text { ÄDEL? } \\ & & & \text { Återgång till offentlig } \\ \text { drift }\end{array}$

Förändringarna i omsorgsklimat tyder på en förändrad karaktär i omsorgsarbetet, speciellt med tanke på minskningen av vänskapligt klimat och ökningen av rationellt klimat år 2002/2003. Det kan stå för en minskad kontakt mellan vårdbiträde och vårdtagare och att arbetet har blivit mer inriktat på speciella arbetsuppgifter än på helheten i hjälpsituationen. Rationaliseringar har genomförts vid sista mättillfället och en del uppgifter som inköp och städning har överlämnats till privata entreprenörer.

\section{Privaten 2, kommun C}

I Privaten 2 är personalen 1993 nyrekryterad och grupperna nystartade (se Figur 8). En del av personalen har tidigare varit anställd inom kommunal hemtjänst. En kommunikationsklyfta mellan bistånds- handläggarna och arbetsgrupperna är tydlig i våra observationer. Missförstånd sker när det gäller uppdragens innebörd (Olsson \& Ingvad 2000). Ett nytt företag tar över verksamheten 1997, vilket har ett ekonomiskt avtal med kommunen som tillåter dem att minska på personalen. 2001 sker återgång till kommunal drift. Distriktet styrs därefter av en stark förvaltningschef.

Andelen osäkert klimat ökar genom mätningarna till ett förhållandevis högt värde 2002/2003, medan förändringarna i de andra typerna av klimat är små. Uppgången i osäkert klimat kan höra samman med de många förändringarna under den undersökta perioden. Dessa har inneburit förändrad driftsledning ett flertal gånger, förändrad sammansättning av arbetsgrupperna och växling av arbetsledare. Alla dessa förändringar kan medföra byte av vårdbiträden för vårdtagarna och oklarheter i kommunikationen mellan vårdtagare 
och verksamheten. Återgången till kommunal drift beror bl.a. på missnöje från den politiska ledningen med det privata företagets sätt att sköta verksamheten.

\section{Jämförelse mellan distrikten}

Vid jämförelse mellan distrikten vid respektive mättillfälle finner vi att skillnaderna 1995 är statistiskt signifikanta (Chisquare $=34,8 \mathrm{p}<0,05)$. Distrikten Centrum, Privaten 1 och Kommunal har hög proportion av osäkert klimat. Distrikten Ekvallen, Moheden, Slätten och Privaten 2 har hög proportion av vänskapligt klimat. 1997 föreligger ingen statistiskt signifikant skillnad mellan distrikten. Dessa är således vid denna tidpunkt mer lika varandra när det gäller omsorgsklimat. Dock har distrikt Ekvallen en mycket låg proportion av osäkert klimat. 2002/2003 är skillnaderna mellan distrikten större igen, men denna skillnad är inte statistiskt signifikant (Chisquare $=27,4 \mathrm{p}=0,072$ ). De båda distrikt som haft privat entreprenör har högst andel osäkert klimat och de små distrikten Ekvallen och Slätten har lägst andel.

\section{Analys av samband mellan omsorgsklimat och organisationsform}

Regressionsanalyser har genomförts för var och en av de fyra omsorgsklimatfaktorer som ingår i klimatprofilerna, för att studera inverkan av bl.a. organisationsformen (se Tabell 4).

Regressionsanalysen visar att utplattning, arbetsbörda och mättillfälle (tidsförlopp) i olika grad och på olika sätt påverkar omsorgsklimatet. Överlag är sambanden svaga, men vi uppnår ändå statistisk signifikans. Ju mer utplattad organisationen är desto högre osäkerhet och lägre kommunikation bedömer vårdtagarna. Ju större andel vårdtagare med daglig vård desto högre närhet och lägre kommunikation anger vårdtagarna. Det är rimligt att daglig

\section{Tabell 4.}

Regressionsanalyser av faktorerna i vårdtagarnas upplevelse av omsorgsklimatet. Kommunoch distriktsstorlek, grad av delad organisation, grad av utplattning, grad av arbetsbörda (andel vårdtagare med daglig vård) och mättillfälle ingår som oberoende variabler.

\begin{tabular}{|l|l|l|l|}
\hline Omsorgsklimatfaktor & Organisationsvariabler & Betavärde & $\mathbf{R}^{\mathbf{2}}$ \\
\hline Osäkerhet & Mättillfälle & $\begin{array}{l}0,09 * * \\
0,08^{*}\end{array}$ & 0,02 \\
& Utplattningsgrad & $\begin{array}{l}0,11^{* *} \\
-0,09 *\end{array}$ & 0,02 \\
\hline Närhet & $\begin{array}{l}\text { Arbetsbörda } \\
\text { Distriktsstorlek }\end{array}$ & & \\
\hline Kontroll/Ordning & - & $-0,1)^{* *}$ & 0,02 \\
\hline Kommunikation & $\begin{array}{l}\text { Utplattningsgrad } \\
\text { Arbetsbörda }\end{array}$ & $-0,08^{*}$ & \\
\hline
\end{tabular}

${ }^{*} 0,01<\mathrm{p}<0,05{ }^{* *} 0.001<\mathrm{p}<0,01$

Ingvad, Olsson, Bondesson \& Arndt: Organisationsförändring, omsorgsklimat... 
vård ger en större emotionell närhet och att olika funktionsnedsättningar hos vårdtagaren bromsar spontaniteten i det kommunikativa utbytet. Distriktsstorleken har betydelse för närheten. Ju större distrikt desto mindre närhet, vilket kan tillmätas en ökad anonymitet i relationen i de större distrikten. I de små distrikten kan det kanske ofta finnas en kännedom om varandra redan innan man möts som vårdtagare och vårdgivare.

Oberoende av andra variabler ökar faktorn osäkerhet över tiden. Detta kan tänkas höra samman med övergången till att erbjuda hemtjänst främst till dem som behöver mycket hjälp, en generell effektivisering och en förändrad karaktär i hemtjänstarbetet. Dessa förändringar ökar eventuellt osäkerheten och irritation hos vårdtagarna angående vad de kan förvänta av vårdbiträdet.

Inga samband förekommer när det gäller delning av organisationen i beställare-utförare. Denna förändring tycks inte ha en entydig påverkan på hur vårdtagaren upplever relationen till vårdbiträdet. Vi kan också notera att inga organisationsförändringar enligt regressionsanalysen påverkar omsorgsklimatet i en positiv riktning.

\section{Diskussion}

I denna studie har vi undersökt hur kvaliteten i omsorgsarbetet inom hemtjänsten påverkas av hur organisationen konstrueras. De samband som framkommer i den statistiska analysen är svaga, vilket tyder på att andra faktorer också spelar en roll. De samband vi har funnit bildar ett intressant mönster. Utplattningsgraden kan tolkas bidra till högre osäkerhet hos vårdtagarna och sämre kommunikation med vårdbiträdet. Detta kan knytas till ledarskapet, som i distrikt med högre utplattningsgrad präglas av låg tillgänglighet. Just tillgängligheten till arbetsledaren har i tidigare studier visat sig vara betydelsefull för arbetsgruppens klimat (Olsson \& Ingvad 2001, Olsson et al. 1995). Gruppklimatet kan i sin tur påverka andelen osäkert klimat hos vårdtagarna. $\mathrm{Vi}$ antar att ett försämrat ledarskap leder till olika problem i arbetet, t.ex. att vårdbiträdena upplever mindre stöd i påfrestande situationer och blir osäkra i sin yrkesroll, vilket i sin tur påverkar vårdtagaren.

Även om vi inte ser någon försämring av omsorgsklimatet till följd av beställar-utförarmodellen i organisationen så kan vi inte heller se några entydiga positiva effekter av denna organisationsform. Den tycks inte spela någon roll för kvaliteten i relationen mellan vårdbiträde och vårdtagare. En bedömning av biståndet från en särskild specialiserad biståndsbedömare tycks inte leda till att relationen mellan vårdtagare och vårdbiträde blir tryggare eller mer tillfredsställande när det gäller kommunikationen. När det gäller privatisering av hemtjänsten är vårt material osäkert då enbart distrikt Privaten 1 genomgående har lagts ut på entreprenad. $\AA$ andra sidan har detta distrikt ett successivt försämrat omsorgsklimat till en mycket hög nivå av osäkerhet hos vårdtagarna.

Analysen av varje distrikt för sig visar inte några helt konsekventa relationer mellan organisationsförändringar och vårdtagarnas upplevelser av omsorgsklimat. Förändringar kan i ett distrikt synas leda till 
försämringar av omsorgsklimatet och i ett annat distrikt snarast ha motsatta effekter. Skillnaderna mellan distrikten med olika organisation är tydligare för 1995, då vi kan anse att effekterna av utplattning och delning i organisationen i tidigt 1990-tal har nått sin kulmen. Likaså finns det tydliga skillnader mellan distrikten vid början av 2000-talet. Dessa senare skillnader kan bero på att några distrikt företagit omfattande förändringar medan andra varit mer stabila. Distriktet Ekvallen i kommun A har inte företagit några omfattande förändringar. Detta distrikt uppvisar det mest positiva omsorgsklimatet i stort sett under hela studieperioden. Distriktet har emellertid en serie speciella egenskaper genom t.ex. ett lågt invånarantal och samma ledarskap under hela perioden. Omsorgsklimatet är stabilt i jämförelse med det lilla distriktet $i$ kommun $B$, som genomgått mer omfattande förändringar.

Våra resultat pekar på att 1990-talets organisationsförändringar inom äldreomsorgen generellt har lett till en ökad klyfta mellan vårdtagare och verksamheten. Effekterna av genomförandet av beställarutförarmodellen kan belysas utifrån den domänteori som utvecklats av Kouzes och Mico (1979) (se också Kronvall et al. 1991). Enligt denna består offentliga organisationer av tre skilda domäner: politisk domän (beslutsfattande), administrativ domän (styrning) och professionell domän (uppgiftslösning). Domänerna kan enligt teorin hävda skilda och motstridiga uppfattningar om organisationens uppgift, arbetsmetoder och ha olika definitioner av kvalitet. Organisationsförändringarna inom äldreomsorgen har inneburit en ökad kontroll för administrationen över hur de ekonomiska medlen används, hur omsorgen till de äldre fördelas och hur beslut om verksamheten tas. I alla dessa frågor dominerar den administrativa domänen i organisationen med ökad regelstyrning och stor möjlighet att kontrollera personalen. Den professionella domänen har fått svårigheter att hävda sina bedömningar av de äldres behov och sina anspråk på arbetsmiljön, t.ex. villkoren för arbetsgruppen när det gäller behov av ledning.

Organisationerna inom hemtjänsten idag är av samma slag som på 1990-talet, trots att dessa har inneburit en försämrad omsorgskvalitet för de äldre. Dessa organisationsformer kan inte heller försvaras utifrån den administrativa domänens behov av kostnadskontroll, då det inte finns några otvetydiga stöd för att organisationsförändringarna leder till bättre kostnadseffektivitet (Edebalk \& Lindgren 1995). Det finns därför anledning att ytterligare studera konsekvenserna av äldreomsorgens organisation och diskutera dess utformning. 


\section{Referenser}

Andersen, N A (2000) „Public Market - Political Firms". Acta Sociologica, 43, s. 43-61.

Aspelin, J (1999) Klassrummets mikrovärld. Stehag: Symposion.

Blomberg, S (2004) Specialiserad biståndshandläggning inom den kommunala äldreomsorgen. Lund: Dissertations in Social Work 17. Lunds universitet, Socialhögskolan (Akad avh).

Edebalk, P G \& Lindgren, B (1995) „Den nya äldreomsorgen." Nordiskt socialt arbeid, 4, s. 269276.

Fuglsang, L (2001) „Management problems in welfare services: the role of the 'social entrepreneur' in home-help for the elderly, the Valby case." Scandinavian Journal of Management 17, s. 437-455.

Gilbert, D C \& Levinson, D J (1956) „Ideology, Personality, and Institutional Policy in the Mental Hospital." Journal of Abnormal and Social Psychology, vol. 53, s. 263-71.

Ingvad, B (2003) Omsorg och relationer. Om det känslomässiga samspelet $i$ hemtjänsten. Lund: Dissertations in Social Work 15. Lunds universitet, Socialhögskolan (Akad avh).

Ingvad, B \& Olsson, E (1999) „Det känslomässiga utbytet och omsorgskvalitet i hemtjänsten." Socialvetenskaplig tidskrift, vol. 6, nr 1, s. 3-26.

Kitchener, M (1998) „Quasi-market transformation: An Institutionalist Approach to Change in UK Hospitals." Public Administration, Spring 1998.

Kouzes, J \& Mico, P (1979) „Domain Theory: An Introduction to Organizational Behavior in Human Service Organizations." The Journal of Applied Behavioral Science, vol. 15, nr. 4, s. 449-469.

Kronvall K, Olsson E \& Sköldborg T (1991) Förändring och lärande. Lund: Studentlitteratur.

Lewin K, Lippit R \& White R K (1939) „Patterns of Aggressive Behavior in Experimentally Created 'Social climates'». Journal of Social Psychology, nr 10, s. $271-299$.

Mackenzie, K R (1981) „Measurement of Group Climate. Int J Group Psychother, 31(3), July. O’Driscoll, M P \& Evans, R (1988) „Organizational
Factors and Perceptions of Climate in Three Psychiatric Units." Human Relations, vol. 41, nr. 5, s. 371-388.

Olsson, E (1998) På spaning efter gruppens själ. Gruppen i teori och praktik. Lund: Studentlitteratur.

Olsson, E \& Ingvad, B (2000) Köp, sälj och platta till! Organisationsförändringar, arbetsmiliö och omsorgskvalitet $i$ hemtjänsten under 1990talet. Meddelande från Socialhögskolan 2000:7. Lund: Socialhögskolan, Lunds universitet.

Olsson, E \& Ingvad, B (2001) »The emotional climate of care-giving in home-care services." Health and Social Care in the Community, 9:6, s. 454-463.

Olsson, E \& Ingvad, B (2004) 1990-talets hemtjänstorganisationer. En longitudinell studie av organisation och kvalitet $i$ hemtjänsten 1993-2003. I manuskript.

Olsson, E \& Ingvad, B (2006a) „Organisationer, kvalitet och arbetsmiljö i hemtjänsten under 1990-talet." Arbetsmarknad \& Arbetsliv, 12:1, s. 5-16.

Olsson, E \& Ingvad, B (2006b) „Relationer i formell och informell hjälp med daglig livsföring till äldre." Working-paper 2006:9. Internetpublicering. Lunds universitet, Socialhögskolan.

Olsson E, Ingvad B, Bondesson K \& Arndt C (2005) „Organisationsförändring och arbetsgruppsklimat." I I Karlsson, K Törnblom \& R Vermunt (red.) GRASP 2004. Proceedings of the 4th Nordic Conference on Group and Social Psychology. Skövde: Högskolan i Skövde, institutionen för teknik och samhälle/socialpsykologi.

Olsson E, Ingvad B \& Hansson K (1995) "Arbetsorganisation och gruppklimat i hemtjänsten." Socialvetenskaplig Tidskrift, vol 2, nr. 3, s. 227248.

Rapoport, R N (1960) Community as Doctor: New Perspectives on a Therapeutic Community. London: Tavistock.

Rogers C, Gendlin E T, Kiesler D \& Truax C (1967) The Therapeutic Relationship and its Impact: a Study of Psychotherapy with schizophrenics. 
Westport: Greenwood Press.

Socialstyrelsen (2004) Konkurrensutsättning och entreprenader inom äldreomsorgen. Utvecklingsläget 2003, 2004-131-12.

Szebehely, M (1995) Vardagens organisering. Om vårdbiträden och gamla $i$ hemtjänsten. Lund: Arkiv (Akad avh).

Szebehely, M (2000) "Äldreomsorg i förändring - knappare resurser och nya organisationsformer.u I SOU 2000:38 Välfärd, vård och omsorg. Antologi från Kommittén välfärdsbokslut.

Timko, C \& Moos, R H (1991) "A Typology of Social Climate in Group Residential Facilities for Older People.» Journal of Gerontology, 46, s. 160-169.

Trydegård, G-B (2001) „Välfärdstjänster till salu. Privatisering och alternativa driftformer under 1990-talet." I SOU 2001:52 Välfärdstjänster $i$ omvandling. Antologi från Kommittén välfärdsbokslut.

Ware P, Matosevic T, Forder J, Hardy B, Kendall J \& Knapp M (2001) »Movement and change: Independent sector domiciliary care providers between 1995 and 1999." Health and Social Care in the Community, 9:6, s. 334-340.

\section{Summary}

\section{Organizational change, caring climate and quality of care in the home help services}

During the 1990s public elderly care in Sweden was radically reorganized. A majority of the municipalities in Sweden have introduced some form of the purchaser/ provider model.

A longitudinal study of the organizations and of the care recipients' and the home helpers' perception of their relationship was carried out in seven districts of home help service in three municipalities during a 10-year period (1993-2003). This article examines the effects of the various organizational changes in these districts on the care recipients' perception of the emotional climate of the relationship to the home helper, conceptualized as the caring climate. The material was collected through qualitative studies of the organizations and questionnaires to the recipients at three different times. The caring climate was measured according to a previously developed method.

The organizational changes that most explicitly affect the recipients' perception of the caring climate have to do with the closeness and accessibility of the management, i.e. the degree of flattening contributes to the experience of greater insecurity and poorer communication in the relationship to the home helpers. The results are uncertain when it comes to the private contractors. This district, however, saw a gradual worsening of the caring climate during the period of study in comparison to the other districts in the study. 